Maurer School of Law: Indiana University Digital Repository@ Maurer Law

Articles by Maurer Faculty

Faculty Scholarship

1929

\title{
Some Implications of Juristic Pragmatism
}

Fowler Vincent Harper

Indiana University School of Law

Follow this and additional works at: http://www.repository.law.indiana.edu/facpub

Part of the Jurisprudence Commons, and the Law and Philosophy Commons

\section{Recommended Citation}

Harper, Fowler Vincent, "Some Implications of Juristic Pragmatism" (1929). Articles by Maurer Faculty. 2520.

http://www.repository.law.indiana.edu/facpub/2520

This Article is brought to you for free and open access by the Faculty Scholarship at Digital Repository @ Maurer Law. It has been accepted for inclusion in Articles by Maurer Faculty by an authorized administrator of Digital Repository @ Maurer Law. For more information, please contact wattn@indiana.edu.

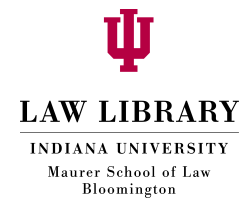


$\mathrm{NE}$ of the disconcerting factors about the study of jurisprudence is the variety of meaning which the term conveys. All are familiar with the looseness with which the expression is used, and one is at once cautious to designate clearly the limitations with which his usage is to be attended. The result is that classifications have been made which tend to distinguish jurisprudence from broader and more narrow fields of legal investigation. ${ }^{1}$ German writers set jurisprudence over against the philosophy of law, both being subdivisions of the "science of law," in the broad sense. ${ }^{2}$ One effect of such classification is to emphasize the distinctions between jurisprudence, as the science of law in the narrow sense, and the philosophy of law, at the expense of recognizing the relation between them. It is submitted that jurisprudence, in this restricted sense, should be regarded as dependent upon philosophy of law, or, as some will have it, the philosophy of law as dependent upon jurisprudence. ${ }^{3}$ The interrelation between the two seems to be such that the two propositions are interchangeable, for each field is indispensable to the other. ${ }^{4}$

It is true, as everyone knows, that for a long time now, legal philosophy has been in ill repute. This indeed is a monstrous situation when the investigation of "fundamental principles" is thus neglected. But it may very well be because legal philosophy has had in many years but little to offer a

${ }^{1}$ Cf. Rottschafer, "Jurisprudence: Philosophy or Science," Minn. Law Rev., XI (I927), 293.

${ }^{2}$ See Gareis, Science of Law, p. I5 $_{5}$ ibid. (I9+1), p. 22 , n. 3.

${ }^{3}$ See Miraglia, Comparative Legal Philosophy (I9I2), p. 89.

${ }^{4}$ Cf. Berolzheimer, The World's Legal Philosophies (1924), p. Io. 
world of workingmen and working ideas. But there are signs of a change of front, and the interest in philosophical investigation is unquestionably increasing rapidly. The reasons for this are not far to seek. General philosophy is tending to restrict its field to include only such philosophic propositions as can be investigated by means of the modern scientific method, by which is meant the method of observation, experiment, and trial hypothesis as commonly used by men of science since the days of Kepler and Copernicus. ${ }^{5}$

By such a conception of the philosophy of law, there is at once a tendency to eliminate the speculation upon those propositions about law which, by hypothesis, are incapable of being proved. That this does not inordinately hamper the province of legal philosophy is at once clear when it is remembered that in many such propositions it can never be shown that there is, in fact, any problem to be solved. ${ }^{\circ}$

Then again, by confining philosophical investigation in law to those propositions which may be attacked with the temper of the scientific spirit and which may be subjected to scientific processes, the great and constant threat to legal philosophy is at once eliminated. An entire system of juristic philosophy need not crumble into nothingness the instant that science and experience detect some fatal flaw in the data upon which it is reared. An analogy may be drawn from the effect upon philosophy generally of the new physics with its complete abandonment of the notion of cause, which effect has been so pressed upon philosophic and scientific men generally; or from the effect of modern astronomy upon the older notion

'Cf. Russell, "Scientific Method in Philosophy," Logic and Mysticism and Other Essays (1925), p. 97.

${ }^{6}$ Cf. Tourtoulon, Philosophy in the Development of Law (I922), pp. 26-27. "Two radically different reasons, however, may be given as to why a problem is insoluble. One reason is that the problem is too high for intelligence; the other is that the question in its very asking makes assumptions that render the question meaningless. The latter alternative is unerringly pointed to in the celebrated case of design v. chance" (Dewey, Influence of Darwin, etc., p. 14). 
of a "universe" as opposed to a "multiverse." We are reminded by a scientific philosopher:

In the days before Copernicus the conception of the "universe" was defensible on scientific grounds: the diurnal revolution of the heavenly bodies bound them together as all parts of one system, of which the earth was the center. Around this apparent scientific fact, many human desires rallied: the wish to believe Man important in the scheme of things, the theoretical desire for a comprehensive understanding of the whole, the hope that the course of nature might be guided by some sympathy with our wishes. In this way, an ethically inspired system of metaphysics grew up, whose anthropocentrism was apparently warranted by the geocentrism of astronomy. When Copernicus swept away the astronomical basis of this system of thought, it had grown so familiar and had associated itself so intimately with men's aspiration, that it survived with scarcely diminished force-survived even Kant's "Copernican revolution," and is still now the unconscious premise of most metaphysical systems. ${ }^{7}$

This survival is nowhere better illustrated in legal philosophy than in the "universal" conception of the various philosophies of the law of nature prior to the modern distinctions between form and content of the neo-Kantian school. Older natural-law philosophies, especially those which survived in American law, ${ }^{8}$ represented the older philosophic concept of the eternally valid or universal law, a relic of medieval astronomy, to which positive law must conform and by which it could be measured. ${ }^{\circ}$

That both philosophy and science must deal with the same subject matter is now so generally conceded that both philosophers and scientists are beginning to recognize it. ${ }^{10}$ If, then, the philosophy of law be regarded as seeking to clarify the method of law, to rationalize its processes and to furnish

${ }^{7}$ Russell, op. cit., p. 99.

${ }^{8}$ See Haines, "The Law of Nature in State and Federal Judicial Decisions (I9I6)," Yale Law Jour., XXV, 6I7; Harper, "Natural Law in Constitutional Theory," Mich. Law Rev., XXVI (I927), 62.

${ }^{\circ} \mathrm{Cf}$. Pound, Interpretations of Legal History (1923), pp. 5-6.

${ }^{10} \mathrm{Cf}$. Storek in Journal of Philosophy, XXIII (1926), 22, reviewing H. W. Carr, Scientific Approach to Philosophy (1924). 
tests and criteria for the attainment of its ends so that the consequences of law can be subjected to the devastating fire of applied science, there is at once provoked a field of study which is capable of inquiry upon purely empirical bases, and one which affords a tangible subject matter.

But whence, it may be asked, is such a philosophy of law to come? Must there be constructed from the whole cloth an entire new system of legal thought, or is it to spring full blown from the science of law? In truth, the yeast of various positivistic philosophies has been working in the law for many years, manifesting itself in various forms. For a score of years, now, since the interest in America has been focused upon sociological jurisprudence, there have occurred not infrequent hints in the literature of the philosophy of law which must eventually emerge. Old ways of thinking, sometimes called by new names, at frequent intervals threaten to develop into a systematic philosophic program in law. And yet, though it is strange indeed, a pragmatist philosophy of law has failed definitely to appear or to be as boldly proclaimed as might be expected, ${ }^{11}$ although measureable success is accompanying experiments in some quarters.

Pragmatism no doubt has much that is useless for law and doubtless for an enduring philosophy of any sort. Its theory of the knowledge process and James's radical empiricism seem to offer little help for law. There has been, no doubt, enough of metaphysics in modern legal speculation. Further there is no more need for a new method for preserving and for justifying the rubbish of the law than there is need for a new process of justifying the rubbish of religion or of ethics. But pragmatism with its empirical bases and its eye directed toward fruits and consequences can surely be retained as ground for the superstructure which is developing upon it.

What has pragmatism, then, to offer that is particularly tempting to the law? It offers an empirical and scientific way

\footnotetext{
${ }^{11}$ See Wu's reference to the pragmatist jurist, Ill. Law Rev., XVIII (I924), $285,286$.
} 
of thinking that is peculiarly capable of transplanting directly into the loam of Anglo-American law. It directs the legal philosopher to answers for his problems that fit strikingly well into the common-law system.

Consider, if we may, the pragmatist thesis. "The truth of an idea is not a stagnant property inherent in it. Truth happens to an idea. It becomes true, is made true by events. Its verity is in fact an event, a process; the process of its verifying itself, its verification. Its validity is the process of its validation."12

To the sociological jurist this is indeed not unfamiliar, for it is the bald statement of a thesis which must form the justification of his method. And yet the effect of such a philosophy boldly and deliberately applied to legal phenomena is startling. Every rule of law is just or unjust as, and according to, its subsequent justification. Justice becomes an attribute of the legal rule by way of its relation to subsequent experience. The justice of the rule is, in fact, the process of its justification. In Judge Cardozo's phrase, "there is an endless 'becoming, ${ }^{\prime 13}$ and it is toward this that the eye of the pragmatist jurist is directed.

Thus the decision in every case is a projection into the future and a prophecy of the effect upon the social order of the conduct thus regulated. Now the "just" becomes merely the expedient in adapting the legal order to the social and economic structure. The legal rule enunciated in a decision becomes but a "working hypothesis" which will be demonstrated, experientially, to be sound or unsound. The rule will be just or unjust as its consequences reveal. ${ }^{14}$ As law for Justice Holmes means prophecies of what the court will do; so, just law for the pragmatist jurist means prophecies of what will

${ }^{12}$ James, Pragmatism (r9I4), p. 20I ; Preface, Meaning of Truth (I9II), p. vi.

${ }^{13}$ Nature of the Judicial Process (1922), p. 28.

${ }^{14}$ Cf. More, Ethics, chap. v. The "consequences," however, include the present as well as the future. Cf. Tufts, Creative Intelligence, p. 384. 
produce the most satisfactory and most desired consequences, in the main and on the whole view.

The pragmatist tool is logic, but logic of an experimental type as the only kind consistent with the pragmatist viewpoint. By this logic there is substituted, in Professor Dewey's words, "the method of search and discovery" for the old syllogistic process. The logic that lends consistence and systematization to the law is not abandoned, but it is made purely "instrumental" rather than an end in and for itself. ${ }^{16}$ Thus the instrumental view of logic is founded in and may be said to be a part of the pragmatic process. A pragmatist philosophy of law will be the theory of the synthetic process of co-ordinating the legal materials with desire, with experimental logic as its working tool.

Law, from this standpoint, becomes a part of the general scheme of instruments for readaptation. It but assists society in its experiments of readjustment. Every application of a rule of law is a prophecy, good or bad, as to conditions necessary to make the future satisfactory. It thus requires in every case, verification-in the strict legal sense, justification. The whole genius of the pragmatic attitude is that it has no theory of reality, and in law it will have no unprovable presuppositions about abstract justice. It has been called an "emancipated empiricism" and is content, says Dewey, to "take its stand with science." $" 17$

It has been said that law is not like the physical sciences in that its subject matter is a physical phenomenon to be accounted for by a theory worked out by observation of facts, ${ }^{18}$ but nevertheless the consequences of the social phenomena which constitute the subject matter of law are capable of observation, and legal hypotheses can be tested by experience

15 "Logical Theory in Law," Corn. Law Quart., X (I925), I7, 2 I.

${ }^{16}$ Ibid., p. I9.

${ }^{17}$ Creative Intelligence ( 1917 ), p. 55 .

${ }^{18}$ Pound, "Scope and Purpose of Sociological Jurisprudence," Harv. Law Rev., XXV (I9I2), 598. 
and validated or invalidated. Physical science formerly accepted as its fundamental premises a priori assumptions which were regarded as self-evident, and the revolutionary character of the modern scientific method must be ascribed to its elimination of such a priori categories and its concentration upon the consequences of hypotheses. ${ }^{19}$ Scientific philosophizing, accordingly, formulates as explanations of these hypotheses nothing but certain "empirical generalizations," which can themselves be modified from time to time when the working hypotheses are corrected by the consequences in experience which follow.

From unexpected sources there come indications of the attitude of the pragmatist in the philosophy of law. Especially is this true where the sociological school has made headway. In America, the most brilliant exponent of sociological jurisprudence has been pronounced "a thoroughgoing pragmatist." ${ }^{20}$ Vander Eycken finds that "it is no longer in texts or in systems derived from reáson that we must look for the source of law; it is in social utility, in the necessity that certain consequences shall be attached to given hypotheses." ${ }^{\prime 21}$

The movement on the Continent for "free judicial decision" has behind it, in some quarters at least, a juristic pragmatism. In Germany, where the transcendental philosophies of the neo-Hegelian and neo-Kantian schools are strong, this is not so noticeable, but in Gény we find significant indications of a philosophy which is, in method, not inconsistent with science. He says:

Now it cannot be repeated too often that legal science is essentially a science of action, having no purpose except that of finding the necessary rules for the government of certain human relations by external social sanctions. It is based on facts of social life which it aims to order and

${ }^{19}$ Cohen, "Place of Logical Theory in Law," ibid., XXIX (I9I6), 622, 63I-32.

${ }^{20}$ See Wu, op. cit., XVIII, $285,297$.

${ }^{21}$ Méthode positive de l'Interprétation juridique, p. 40I, quoted by Judge Cardozo, Nature of the Judicial Process, pp. I21-22. 
arrange in such a way that the consequences flowing from them are those which are socially desirable. ${ }^{22}$

The connection between sociological jurisprudence and juristic pragmatism is not difficult to understand. Sociological jurisprudence demands a pragmatist philosophy of law-in fact, it presupposes it. Dean Pound has pointed out, in his critique of sociological jurisprudence, five characteristics of the sociological jurist, ${ }^{23}$ every one of which is teleological, in the broad sense, namely, by assuming a system wherein purposes are realized within wider or more narrow limits. The necessity for a pragmatist attitude in philosophy is consistent with none but the teleological method in science. ${ }^{24}$

Sociological jurisprudence has pointed law toward social justice and has assumed that law must seek to attain certain ends. What it needs is (I) a philosophy which will explain its method and furnish it with a rationale; and (2) one which will provide the sociological jurist with tools and show him how to use them by (3) furnishing him with some scale of values by which he can hew his way through the experiential flux of the legal order.

Jhering's great thesis, as everyone knows, provides a method which in its bare form but puts off the ultimate problem. ${ }^{25}$

22 "Judicial Freedom of Decision," Science of Legal Method (I912), p. I6.

${ }^{23}$ "Scope and Purpose of Sociological Jurisprudence," Harv. Law Rev., XXV (I9I2), 489, 5I2-I6.

${ }^{24}$ Cf. Dewey, "Philosophic Method," Experience and Nature (1925), p. 37. "The purport of thinking, scientific and philosophic, is not to eliminate choice but to render it less arbitrary, and more significant. It loses its arbitrary character when its quality and consequences are such as to commend themselves to the reflection of others after they have betaken themselves to the situations indicated; it becomes significant when reason for the choice is found to be weighty, and its consequences momentous. This statement is not a commendation of the will to believe. It is not a statement that we should choose, or that some choices are self-justifying. It is a statement that wherever reflection occurs and intelligence operates, a selective discrimination does occur. The justification of a choice is wholly another matter; it is extrinsic. It depends upon the extent in which observation, memory and forethought have entered into making the choice, and upon the consequences that flow from it. When choice is avowed, others can repeat the course of the experience; it is an experiment to be tried, not an automatic safety device."

${ }^{25} \mathrm{Cf}$. Gény, op. cit., pp. I3-I4. 
Sociological jurisprudence, in its more developed form, while it lends direction to, yet does not completely fix, the empirical limits of the juristic process. There is still wanting a systematic philosophy of law. Sociological jurisprudence is a method in the science of law, while juristic pragmatism is a scientific method in the philosophy of law. Experimental logic is the actual juristic tool with which the work is performed. As auxiliary equipment, for purposes of testing hypotheses through examinations into their consequences, there must be legal sociology, legal economics, and the behavioristic ethics which is in the process of formulation. Thus the functional study of law extends the juristic process and furnishes means by which recurring checks can be made. As Dean Pound predicted, some years ago, "the sociological movement in jurisprudence is a movement for pragmatism as a philosophy of law . . . . for putting the human factor in the central place and relegating logic to its true position as an instrument." ${ }^{26}$

But if the sociological movement presupposes a pragmatist philosophy in law, it does so no more than other characteristics of American legal thought. Pragmatism has been regarded as peculiarly American and particularly adapted to the culture of a people of our experience. It is not inconsistent with the spirit and methods of the common law. Judge Cardozo has declared that "the juristic philosophy of the common law is at bottom the philosophy of pragmatism," ${ }^{, 27}$ and Dean Pound has described the process which only juristic pragmatism can explain as one of the "purely juristic methods of systematizing the judicial finding of law." He continues:

This method, in appearance crude and unscientific, is none the less justified by its results. It is, in truth, the method of the natural scientist, of the physician and of the engineer, the method of trial hypothesis and confirmation. The tentative results of a priori reasoning are corrected continually by experience. A cautious advance is made at some point. If just results follow, the advance goes forward and in time a rule is devel-

${ }^{28}$ "Mechanical Jurisprudence," Colo. Law Rev., VIII (I908), 605, 609-10.

${ }^{27}$ Nature of the Judicial Process (1922), p. ro2. 
oped. If the results are not just, a new line is taken, and so on until the best line is discovered. ${ }^{28}$

There are still other reasons to expect the seeds of pragmatism to flourish in American law. Continental critics of the neo-Hegelian fold have criticized sociological jurisprudence and the entire doctrine of "interests." Berolzheimer says:

Just as well, or just as ill, as on the basis of the "justice based on needs or interests" might cases be decided by the throw of the dice. The "justice based on needs or interests," which in the last analysis may be reduced to Jhering's utilitarian theory, offers an erroneous standard for the weighing of the unweighable. Moreover, it puts profit and advantage in the place of right and justice, so that the function of doing justice would be degraded to a mere act of administration. ${ }^{29}$

But that which here offends this pretentious conception of "justice," which presumably may not always be one with "profit and advantage," is by no means so outrageous to the Anglo-American legal philosopher. The notion of justice which approves and fosters the widespread tendency toward administrative justice and individualized application of law is not only consistent with the thesis of juristic pragratism but is reinforced by such a philosophy. "Administration," declares Pound, "has thus far proved the most effective agency of administrative justice. Thus we may understand the growth of administrative justice which has gone forward so rapidly in the last twenty-five years. Administration had little place in the pioneer, rural, agricultural society of the last century. It belongs to a busy age." ${ }^{30}$ The conditions which the American scene affords and which have produced administrative machinery and the sociological method in juristic science demand likewise a philosophy which is akin to nothing more than to juristic pragmatism.

28 "Courts and Legislation," Science of Legal Method, p. 2I4; cf. Cardozo, op. cit., p. 23 ; cf. Pound, "Theory of Judicial Decision," Harv. Law Rev., XXXVI (I923), 940, 953.

20 "Perils of Emotionalism," Science of Legal Method, p. I72.

30 "Law and Social Work," Ind. Law Jour., III (I927), I83, I89. 
And thus we are brought to realize that not only does juristic pragmatism sanction the teleological method in science, but that it is in complete accord with the evolutionary conception of law. ${ }^{31}$ But herein, again, is there a radical difference between the orthodox historical jurist or the neoHegelian type and the pragmatist philosopher. It is evolution of a different sort. The older evolutionist will disprove, to his entire satisfaction, the entire utilitarian doctrine by showing how "each substantial and fundamental change in the law has been the result of a struggle and the victory of one part of the community over the other-a struggle, to be sure, under the banner of a more modern and advanced idea of justice, and a victory of law purified over a stagnating condition that had come to be felt as unjust.",32

The deterministic attitude here finds expression in the notion of law as something found, rather than made ${ }^{33}$ something to be studied rather than controlled and directed. A pantheistic universe has swallowed up law, leaving nothing but the marks of history. ${ }^{34}$ The kind of evolution characteristic of juristic pragmatism, however, is more modern, and indeed more radical. In the first place, it is free from the presupposition of the old-fashioned evolutionist philosophy which assumes, on strict biological analogy, that all change is for the better. ${ }^{35}$ It will not deny that the "unfolding of the idea of liberty" might very conceivably amount to deprivation of both individual and social freedom. In other words, it is not

${ }^{31}$ Dewey, Influence of Darwin, etc. (I9ro), pp. 8-9.

${ }^{32}$ Berolzheimer, "Perils of Emotionalism," op. cit., p. I7I.

${ }^{33}$ Pound, Law and Morals (1922), p. I6; Interpretations of Legal History (I923), p. I6; "Scope and Purpose of Sociological Jurisprudence," Harv. Law Rev., XXIV (I9II), 59I, 599.

${ }^{84} \mathrm{Cf}$. Tourtoulon, op. cit., p. 617 .

${ }^{35}$ Cf. Russell, Mysticism and Logic, pp. 22 ff.; Russell, "Scientific Method in Philosophy," op. cit., p. I05; cf. Cohen, Editorial Preface to Tourtoulon, Philosophy in the Development of Law, pp. xxv-xxvi; cf. Tourtoulon's discussion of "Progressive Evolution," ibid., pp. $603 \mathrm{ff}$. 
forced to assume that the natural order of things is growth rather than deterioration; progress rather than retrogression. ${ }^{36}$

Now juristic pragmatism maintains that there is nothing inconsistent between a teleological system and a deterministic system. ${ }^{37}$ The historical view is mechanical, not as opposed to organic but as opposed to volitional, and determinism is understood as mechanical determinism. For the pragmatist jurist there is no contradiction in maintaining that the law is both teleological and deterministic because the determinants are not necessarily posited in a system of mechanical causation. Bertrand Russell will insist that it may be teleological and, at the same time, mechanically determined ${ }^{38}$ although we are not to accept Russell's conception of pragmatism nor yet concede the logical positions into which he argues it. ${ }^{39}$

Another important contribution which juristic pragmatism offers is the method of finding some scale for supplying the criteria for judgment. "Value-standards," as they have been called, ${ }^{40}$ are one of the most immediate demands upon the theory of law.

Here it is that the instrumental aspect of judgment is important. Since the scientist's ideas are "working hypotheses" and have value as they enable him to predict and to control, his ideas are the instruments for directing experience, by constructing anticipations and conditions appropriate to their realization. The test of the truth of his idea is in the carrying from anticipation to realization. So, as applied to law as a test of justice, the "workability" of the rule to resolve the difficulty which created the problem in the first place will furnish the

${ }^{36}$ Consequently, we get the conception of responsibility. Cf. Dewey, op. cit., p. I7: "but if insight into specific conditions of value and into specific consequences of ideas is possible, philosophy must in time become a method of locating and interpreting the more serious of the conflicts that occur in life, and a method of projecting ways for dealing with them; a method of moral and political diagnosis and prognosis."

${ }^{37}$ Cf. Russell, "On the Notion of Cause," op. cit., pp. $201 \mathrm{ff}$.

${ }^{38}$ Ibid., p. 208.

${ }^{40}$ See Rottschafer, "Jurisprudence: Philosophy or Science," Minn. Law Rev., XI, 293, $298 \mathrm{ff}$. 
only test possible and the only one necessary. Beyond this, nothing can be demanded of the law. "Hence judgment arises in the self-conscious realization of a problem. . . . . When the difficulty has been apprehended, the judgment emerges as the consciousness of the conditions which will attain the desired end of action freed and unimpaired. ${ }^{\prime 41}$

Just as truth for the pragmatist becomes a class name for all sorts of working values in experience, ${ }^{42}$ so justice for the pragmatist jurist becomes a class name for all sorts of definite working values in legal experience. And as economics long ago gave up the notion of an absolute or real value and recognized that it is want only which makes value, so the juristic pragmatist looks for no value except that which is raised by social and human need. This yields a conception of justice which is organic and synthetic and one which is in constant process of reconstruction. ${ }^{43}$ Values vary directly with wants, and since it is want that is to be measured rather than value in any other sense, the problem is not insurmountable, for sciences other than law are developing pragmatic tools for estimating the intensity of social needs.

\section{II}

So, since "it is the business of legal science to teach the law as it actually works, ${ }^{\prime 4}$ the construction of a scientific philoso-

${ }^{41}$ S. F. McLennan, "Typical Stages in the Development of Judgment," Studies in Logical Theory (1903), pp. 128, 137.

${ }^{42}$ James, Pragmatism, p. 68.

48 "Intelligence and reason imply (a) considering the proposed act or the actually performed act as a whole and in its relations. Especially they mean considering consequences. In order to foresee consequences there is required not only empirical observation of past experience, not only deduction from already formulated concepts-as when we say that injustice will cause hard feelings and revolt-but that rarer quality which in the presence of a situation discerns a meaning not obvious, suggests an idea, 'injustice,' to interpret the situation. Situations are neither already labeled 'unjust,' nor are they obviously unjust to the ordinary mind. Analysis into elements and rearrangement of the elements into a new synthesis are required. This is eminently a synthetic or 'creative' activity" (James H. Tufts, "The Moral Life and the Construction of Values and Standards," Creative Intelligence, pp. 354, 363-64).

${ }^{44}$ Ehrlich, "Judicial Freedom of Decision," Science of Legal Method, p. 77. 
phy of law may well be the logical task of those interested in such fields of thought. That there is a need for such a philosophy cannot more unhappily be illustrated than by the pronouncement of an American judge that in the common law "there are no working hypotheses." ${ }^{45}$

The materials for such a philosophy should be ready and waiting in the actual workings of the law. If the method actually employed in legal science is one that presupposes an experimental philosophy, that method in operation should be expected to reveal the sources for such material. We need not be reminded by Wurzel that the method betrays at once the point of view from which one approaches a subject and will determine different results accordingly. ${ }^{46}$ Since the sociological method is one that is consciously developed by legal science, and since it is consistent with the pragmatic view, we may expect best results from an investigation of opinions which reveal the sociological jurist deliberately pursuing his science, although in view of the empiricism which the common-law system has developed, the attitude of the juristic pragmatist is not deeply latent beneath the entire process.

In considering the complete process of judicial reasoning, it seems obvious that legal science has a unique function to perform. It must establish certain hypotheses from the available legal materials from which the decision in the instant case can be developed, and it must anticipate consequences which will justify and explain the decision when it is reached. But it has been pointed out by Professor Dewey that, as a matter of fact, the conclusion does not follow from the so-called "premises," that the premises and the conclusion are two ways of stating the same thing. The development of the premises and the development of the conclusion are one and the same operation. ${ }^{47}$ It appears in the form of the "giving of reasons" in the

${ }^{45}$ R. L. Fowler, "The New Philosophies of Law," Harv. Law Rev., XXVII (I9I4), 7I8, $72 \mathrm{I}$.

46 "Juridical Thinking," Science of Legal Method, p. 295, n. I3.

${ }^{47}$ Dewey, "Logical Theory in Law," Corn. Law Quart., X (I925), I7, 23. 
opinion of the court. Surely if the court in its opinion is purporting to represent the logical steps through which the judicial mind actually passes in working out the problem, it is fooling no one so much as itself. The entire opinion merely sets forth the hypothesis which is involved over and over again in different forms. Logic has been described as the "derivation of a consequence from a rule or a principle or a precedent which, accepted as a datum, contains implicitly within itself the germ of the conclusion." ${ }^{48}$ What is really important is that we recognize that here a datum of legal experience occurs by refining hypotheses constructed from the legal experience at hand, which themselves anticipate an explanation of that developed datum.

The philosophy of law, if it is to perform its task, must now develop "empirical generalizations" from which the hypotheses which the court has set up may proceed as conclusions. While this is the part of the entire process that is concealed to a greater or less extent, it is here that the ends of law are postulated and that the secret of the method is to be found. Now in so far as pragmatism constructs a thesis which demands a teleological method, it to that extent points laws toward the consequences and demands a technique which the sociological jurist has supplied. Without a juristic pragmatism, however, sociological jurisprudence lacks a rationale and is entirely without a sound philosophical basis.

But philosophy must do more, and pragmatism does more. It must provide some standard whereby to test the decision once it emerges. Hence the decision rendered is but another hypothesis just as those from which it is developed. It is an attempt to control future experience. It is a prophecy of what conditions will produce the realization from the present anticipation. It is to be tested, proved, and justified by its consequences. If it "works," it will be just; if its working value is high, it will to that extent be verified.

${ }^{48}$ Cardozo, op. cit., p. 49. 
Thus it is seen that just as an experimental logic regards the premises of its processes as but working hypotheses, so a juristic pragmatism regards the rule of law enunciated in the decision arrived at as a mere working hypothesis, to be tested by subsequent experience, as sociology, ethics, and the allied sciences shall reveal it.

In this entire process, there is seen the inseparability and interdependence of the science of law and the philosophy of law, ${ }^{49}$ and the necessity for a consistent theory in both. Both demand, moreover, tools which will assist the jurist to arrive at the postulated ends and pursue the prescribed method. Not the least essential to the satisfactory working of the system is the aid of extra-jurisprudential disciplines in checking up on results and measuring the reasons therefor.

By this conception it is seen that the philosophy of law is nothing more than a process. Philosophy and science constitute one co-ordinated system of thought, science being subordinate to philosophy in the logical scheme, but inevitably linked to it. Legal philosophy now proceeds upon no presuppositions whatever except the principles of logic which are not substantive presuppositions at all, but merely such as pertain to the method, not only of philosophy but of all science.

Now the philosophy of law seeks to determine the ends of law and to direct science to the attainment of them. Thereafter it provides for tests for the hypotheses, supplied by the applied sciences. It will be recalled how the analytical method has ever revealed a philosophy of presuppositions of a fatal kind. The procedural presuppositions of the principles of logic assume a substantive form in the syllogism. This has ever been the limitation of the analytical jurist. His method is good so far as it goes, but when it becomes a philosophic system which depends upon the absoluteness of the content of the logical conceptions, it ceases to be serviceable. 285,287 .

${ }^{40}$ Cf. Wu, "The Juristic Philosophy of Roscoe Pound," Ill. Law Rev., XVIII, 
Sociological jurisprudence, however, calls for and must reveal a different philosophy, for in so far as the process of formulating the ends of law is concerned, the "empirical generalizations" from which the hypothesis proceeds are conditioned upon a valid method of determining social needs. Thus when corrections are made upon the hypotheses, where, by competent investigations of a functional nature, the consequences reveal errors in the application of juristic science, there is no invalidation of the philosophy of law. Wherever, then, in an actual opinion, the sociological method is discovered, there should be behind the process a philosophy of juristic pragmatism whether the basic principles are articulate in the opinion or not.

Thus an examination of judicial decisions which have made possible the great flood of social legislation within the past three-score years, completely revolutionizing the legal conception of "due process' of law," proceed from a deep-rooted pragmatist thinking. Hours of labor laws which had formerly outraged the liberty of contract dogma have been found to "work" better than the older hypothesis. ${ }^{50}$ Statutes alleviating conditions of employment, while formerly regarded as "insulting" to the American workingman ${ }^{51}$ have higher working values than decisions which emanated from natural law but left the laborer "free to starve." ${ }^{\text {25 }}$ Freedom of silence guaranteed by "natural right" statutes for employees remove an evil which sociological and economic science lays bare as all too real. ${ }^{54}$ Sterilization laws

${ }^{50}$ Dominion Hotel v. Arizona, I7 Ariz. 267, I5I Pac. 958 (I9I5); State v. Collins, 47 S.D. 325 , r98 N.W. 557 (r923). See Harper, "Due Process of Law in State Labor Legislation," Mich. Law Rev., XXVI (I923), 599.

${ }^{51}$ See Godsharles v. Wigeman, Ir3 Pa. St. 43I, 437, 6 Alt. 354 (I886).

${ }^{52}$ Knoxville Iron Co. v. Harbison, I83 U.S. I3, 46 L.Ed. 55, 22 Sup. Ct. I (I90I).

${ }^{53}$ See St. Louis S.W.R.R. v. Griffin, ro6 Tex: 477, r7x S.W. 703 (r914).

${ }^{54}$ Prudential Insurance Co. v. Cheek, 259 U.S. 530, 66 L.Ed. ro44, 42 Sup. Ct. 5I6 (I922). 
become constitutional when it is demonstrated that society sustains wrongs which are great in comparison with the personal inconvenience which attends a simple operation, ${ }^{55}$ and zoning ordinances are valid when the social standard of aesthetics demands a more workable rule than the old individualist philosophy of the common law could afford..$^{56}$

The common law, too, affords constant evidences of the juristic pragmatism which alone can solve its philosophic problems. A modern commentator on the law of negligence has called to mind two decisions involving the violation of a statute by plaintiff, as a defense. The Vermont court found it good, because the plaintiff was doing an act which was forbidden, and the law consequently imposed no duty upon the defendant to exercise care toward him to protect him from danger. ${ }^{57}$ The Wisconsin court, however, found that plaintiff's violation of the statute had nothing to do with the injury, and consequently it was no defense in an action for negligence. ${ }^{58}$ As some will have it, the decision turned on the proposition that the statute was not designed to relieve the defendant from his wrong. ${ }^{59}$ In any event both decisions were logical enough and both, perhaps, sound. The writer says:

The question was one of sound policy, and the Wisconsin court took one view while the Vermont court took the other. Which was right? There is no right and wrong in such cases. It is a matter of judgment, good taste, an interpretation of the community's desires; in short, law making; at least the bounding of the scope of the protection afforded by the rule of law in question. ${ }^{60}$

Thus when jurists talk of judicial decision, not in terms of a logically determined system or a historical determined phe-

${ }^{55}$ See Justice Holmes in Buck v. Bell, 47 Sup. Ct. 584 (1927).

${ }^{56}$ See Baker, "Constitutionality of Zoning Ordinances," Ill. Law Rev., XX (I925), 2I3.

${ }^{57}$ Johnson v. Irasburgh, 47 Vt. 28 (I874).

${ }^{58}$ Sutton v. Wauwatose, 29 Wis. 2 I (r87r).

${ }^{60}$ Green, "Contributory Negligence and Proximate Cause," N.C. Law Rev., VI (I927), I, I4-I5.

${ }^{60}$ Ibid., p. 15 . 
nomenon, but in terms of "judgment," "good taste," and "interpretation of the community's desire," they are talking in terms of working hypotheses, offensive to any form of natural law. Courts are almost consciously talking juristic pragmatism when they reject hypotheses on the grounds that "precedents drawn from the days of travel by stage coach do not fit the conditions of travel today. The principle . . . . does not change, but the things subject to the principle do change. They are whatever life in a developing civilization requires them to be."

And so, if there is anything characteristic about juristic pragmatism it is that it seeks to bring the law in accord with life and with reality. Contrary to some impressions that pragmatism, by reason of its empirical nature, is concerned only with dead facts, ${ }^{62}$ juristic pragmatism must project its legal hypotheses into the future and have, at all times, one eye pointed in the direction of future experience. Rules of law are only tentative. They do not have, strictly speaking, the quality of justice. It is not a case of "right" or "wrong," but of the most workable regulation of conduct. Thus allowance is made for life and its vicissitudes. Law will not necessarily be logical, for life is illogical. "The moulds expand and shrink." At all times, the law must attempt to look ahead, and it is this foresight which will make for progress in law, and it is the capacity and equipment to make intelligent corrections and modifications that will make the law tolerable and useful to society. $^{64}$ (r9I6).

${ }^{61}$ Judge Cardozo in MacPherson v. Buick Co., 2 I7 N.Y. 382, III N.E. I050

${ }^{62}$ Cf. Kocourek, Introduction to Berolzheimer, The World's Legal Philosophies (I924), p. xx.

${ }^{63}$ Judge Cardozo in Glanzier v. Shepherd, 233 N. Y. 236, I35 N.E. 275 (I922).

${ }^{64} \mathrm{~A}$ well-settled doctrine of equity provides it a defense against a bill for specific performance to show that plaintiff had had knowledge of material facts, obtained through superior instruments and facilities of information, which he failed to disclose and which, although not amounting to actual fraud so as to support a recision, yet results in such a hard bargain that its enforcement would be inequitable 
Often a court, following the common-law tradition of individualism, will purport to turn its decision on grounds reached by a specious legalism, and lip service to dogmas, when, in fact, the real reasons are those explained by juristic pragmatism-looking to the fruits and consequences by a projection into future experience. Thus a court in "balancing the equities" of litigants may argue that "in a case of conflicting rights, where neither party can enjoy his own without in some measure restricting the liberty of the other in the use of property, the law must make the best arrangement it can between the contending parties, with a view to preserving to each one the largest measure of liberty possible under the circumstances." ${ }^{\prime 65}$ In truth, however, the secret is out when the same court puts the problem in other terms: "Shall the complainants be granted, in the way of damages, the full measure of relief to which their injuries entitle them, or shall we go further, and grant their request to blot out two great mining and manufacturing enterprises, destroy half of the taxable values of a county, and drive more than ro,ooo people from their homes?" ${ }^{\prime 8}$

Again, in refusing an injunction to prevent a tannery from polluting a stream which if issued would impair or conclude

(Banaghan v. Malaney, 200 Mass. 46, 85 N.E. 839 [rgo8]). A different situation is presented, however, when it appears that plaintiff's means of information were, in truth, no better if not inferior to defendant's, and plaintiff had no reason to suspect that defendant had not the same information as he. Here there is no reprehensible conduct on plaintiff's part which could be construed as moral culpability. Yet he cannot have specific performance (Cowan v. Sapp, 8I Ala. 525, 8 So. 2I2). (The rule is different, however, in England. Turner v. Green, 2 Ch. 205 [1895]; see discussion of the two cases in Pomeroy, Sec. 2206, n. 94.)

Here the court has not been concerned to base its decision upon the dogma of clean hands. It has gone farther, and looked to the facts and the consequences, finding the bargain quite as hard whether plaintiff has been morally culpable or not. The economics of the cases are the same. By looking to the consequences, both in the immediate situation and in the future, the result has been determined in conformity with the desirability and social utility of those probable consequences.

${ }^{65}$ Madison v. Ducktown Sulphur, Copper \& Iron Co., II 3 Tenn. 33I, 83 S.W. 658, 667, cited in Cook's Cases on Equity (Abr.) (rgo4), p. 365.

${ }^{66}$ Ibid., 83 S.W. 658, 666. 
operation of the industry, the court did not "feel justified in decreeing the issuance of an injunction, the consequences of which would amount to nothing less than a public calamity." ${ }^{\prime 67}$ Already reference had been made to an injunction against a paper mill which had caused it to be shut down for five years. ${ }^{68}$ And so juristic pragmatism may be at the bottom of much discarding of hypotheses which have proved unworkable and hence unjust. Little is heard in modern law of fraud about caveat emptor;" fine distinctions between "affirmations" and "warranties" have ceased to be important in the law of sales;" constant tendencies in the law of torts and credit transactions to distribute loss where it can most easily be carried will readily occur ${ }^{71}$ more socially workable principles will be injected

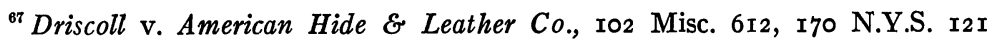
(rgr8), cited in Cook, op. cit., p. 353 , n. r.

${ }^{68}$ Whalen v. Union Bag \& Paper Co., 208 N.Y. I, ror N.E. 805, cited in ibid. (I9I3), p. 35 I. Can the attitude of the pragmatist jurist be more forcefully presented than in the principles which underlie the whole course of the development of equity jurisdiction? "The absence of precedents or novelty in incidence presents no obstacle to the exercise of the jurisdiction of a court of equity. . . . Chancellor Cottinham in Wallworth v. Holt, 4 Myl. \& C. 6r9, says: 'I think it the duty of this court (meaning equity) to adapt its practice and course of proceeding to the existing state of society, and not by too strict an adherence to forms and rules, established under different circumstances, to decline to administer justice, and enforce rights for which there is no other remedy.' Paraphrasing the language of Justice Herrick in Green Island Ice Co. v. Norton, I05 App. Div. 33I, 86 N.Y.S. 6I3, 94 N.Y.S. II47, the jurisdiction of Equity is constantly growing and expanding, and relief is now granted in cases where formerly the courts would not have thought for a moment of so doing. From time immemorial it has been the rule not to grant equitable relief where a party praying for it had an adequate remedy at law; but modern ideas of what are adequate remedies are changing and expanding, and it is gradually coming to be understood that a system of law which will not prevent the doing of a wrong, but only affords redress after the wrong is committed, is not a complete system and is inadequate to the present needs of society" (Judge Dill in Vanderbilt v. Mitchell, 72 N.J.Eq. 910, 67 Atl. 97, cited in Cook, op. cit. [1907], p. 283). $3 \mathrm{I} 7 \mathrm{ff}$.

${ }^{60}$ Cf. Feezer, "Social Justice in Field of Torts," Minn. Law Rev., XI, 3I3,

${ }^{70}$ Cf. Chandelor v. Lopus, Croke Jac. 4, in Williston, Cases on Sales (1625), p. 668, with Un. Sales Act, Sec. I2.

${ }^{71}$ McPherson v. Buick Co., cited supra. 
into the law of defamation $;^{72}$ and the law of evidence will provide hypotheses to produce a greater consistency between their consequences and actual experience. ${ }^{73}$

If a philosophy of juristic pragmatism is worth anything, it will be because it provides legal patterns of thought which are calculated to lay emphasis upon juridical facts and upon social facts; it looks to the first for the hypotheses of the legal order, to the latter for their consequences. It thus confines law to the realities of life and should clear the way for a greater perfection of the sociological method, and, at the same time, lend symmetry and clarity to the legal system.

UNIVERSITY OF OREGON

${ }^{72}$ Even without express statutory authority (Hutchins v. Page, 75 N.H. 215, 72 Atl. 689 [I909]).

${ }^{73}$ Cf. E. A. Harper, arguing for the application of rules of evidence that will produce "a desirable result and one not inconsistent with the reason underlying the rule itself" ("Admissibility of Declarations of Corporate Agents," Univ. of Pa. Law Rev., LXXVI [1927], I, I8). 